\title{
Sosialisasi Kupas Tuntas Covid-19 Berbasis Daring Pada Masyarakat Indonesia
}

\author{
Eko Mulyadi ${ }^{1}$, Budi Yanti ${ }^{2}$ \\ ${ }^{1)}$ Fakultas Ilmu Kesehaan Universitas Wiraraja, \\ ${ }^{2)}$ KSM/Dept Pulmonologi dan Kedokteran Respirasi, Fakultas Kedokteran, \\ Universitas Syiah Kuala, \\ E-mail: byantipulmonologis@unsyiah.ac.id
}

\begin{tabular}{ll}
\hline Article History: & Abstrak: \\
Received: Juli & Kegiatan pengabdian masyarakat ini bertujuan \\
Revised: Agustus & untuk meningkatkan pengetahuan masyarakat \\
Accepted: & Indonesia tentang penyakit virus yang sedang \\
September & mewabah di Negara Indonesia saat ini. Kegiatan ini \\
Available online & dilaksanakan berbasis daring supaya menghindari \\
: Desember & kerumunan masyarakat secara massal dan \\
& mengikuti ajuran kemenkes untuk menekan \\
Kata Kunci: & penularan virus COVID-19. Terdapat empat \\
Covid-19, daring & tahapan pada pelaksanan pengabdian masyarakat \\
& ini meliputi analisis kebutuhan, persiapan, \\
& pelaksanaan dan evaluasi. Kegiatan ini diikuti oleh \\
& 337 peserta, namun hanya 240 peserta yang \\
& bersedia melengkapi form registrasi online. \\
& mencakup seluruh elemen masyarakat dan berasal \\
& dari seluruh Indonesia. Sebagian besar peserta \\
& menunjukkan kepuasan atas kegiatan yang \\
& dilaksanakan dan berharap dilaksanakan sosialisasi \\
& tentang COVID-19 dengan materi yang berbeda \\
& agar pengetahuan masyarakat semakin bertambah.
\end{tabular}

\section{Pendahuluan}

Pandemi coronavirus menyebar dari orang ke orang dalam waktu singkat, selain dampak kesehatan, dampak sosial dan ekonomi merupakan hal yang penting untuk diperhatikan, penyakit ini merupakan penyakit yang relatif baru, sehingga pengetahuan masyarakat tentang penyakit ini masih rendah (Anonymous.,2020). Rekomendasi standar untuk mencegah penyebaran infeksi adalah melalui cuci tangan secara teratur menggunakan sabun dan air bersih, menerapkan etika batuk dan bersin, menghindari 
kontak secara langsung dengan ternak dan hewan liar serta menghindari kontak dekat dengan siapapun yang menunjukkan gejala penyakit pernapasan seperti batuk dan bersin serta dapat menimbulkan kelainan radiologi yang sangat khas (Zhu N, et al., 2020)(Yanti \& Hayatun, 2019)

Pemerintah Indonesia mendesak semua masyarakat Indonesia untuk berpartisipasi dalam menekan penyebaran penularan coronavirus dan secara maksimal melakukan tindakan pencegahan dimulai dari diri sendiri. Masyarakat memiliki peran penting dalam memutus mata rantai penularan COVID-19 agar tidak menimbulkan sumber penularan baru. Mengingat cara penularannya berdasarkan droplet infection dari individu ke individu, maka penularan dapat terjadi baik di rumah, perjalanan, tempat kerja, tempat ibadah, tempat wisata maupun tempat lain dimana terdapat orang berinteraksi sosial. Tindakan pencegahan ini tentu saja dapat mengurangi mortalitas dan morbiditas penyakit (Reluga, 2010).

Kebijakan Pemerintah Indonesia terkait dengan jarak sosial, seperti mengeluarkan perintah untuk belajar dan bekerja dari rumah, tinggal di rumah, menghindari kontak, melarang kegiatan di tengah orang banyak, dan membatasi jam operasi di tempat-tempat umum, mencuci tangan setiap saat dengan menggunakan sabun dan air mengalir selama 40-60 detik, dapat juga memakai cairan antiseptik berbasis alkohol (hand sanitizer) minimal 20 - 30 detik. Mengusahakan untuk selalu tidak melakukan kontak mata, hidung dan mulut dengan tangan yang kotor. Selalu memakai masker bila akan meninggalkan rumah dan melakukan komunikasi dengan orang lain yang belum diketahui status kesehatannya karena dapat memungkinkan terjadi penularan COVID-19. Kebijakan ini diharapkan dapat mengurangi dan mengendalikan penyebaran coronavirus selama periode pandemi ini (Ahn DG., 2020; WHO., 2019).

\section{Metode}

Sosialisasi dilakukan dengan media jejaring sosial elektronik dengan membuat group jejaring sosial dan memasukkan peserta yang mendaftar secara mandiri melalui link pendaftaran elektronik. Terdapat 4 tahapan pelaksanaan sosialisasi ini. Tahap pertama adalah analisis 
kebutuhan, materi dan menetapkan metode sosialisasi. Tahap kedua adalah persiapan materi, menyusun rundown acara, membuat brosur elektronik seperti poster digital dan menerima pendaftaran melalui formulir online yang disebarkan melalui jejaring sosial.

Tahap ketiga adalah Pelaksanaan sosialisasi dilakukan dalam bentuk seminar daring, dengan menggunakan jejaring sosial, materi disampaikan dalam bentuk power point dan rekaman audio. Media ini dipilih mempertimbangkan kemampuan peserta, serta memerlukan koneksi internet relatif minim dengan kapasitas kecil, mengingat kapasitas jaringan internet yang dimiliki peserta juga terbatas. Kemudian dilanjutkan dengan diskusi interaktif dengan peserta. Diskusi dilakukan dalam bentuk teks dan audio. Tahap terakhir adalah evaluasi. Peserta diminta menyampaikan evaluasi dan saran setelah acara selesai dilaksanakan.

Secara ringkas gambaran pelaksanan sosialisasi dapat dilihat dalam diagram berikut.

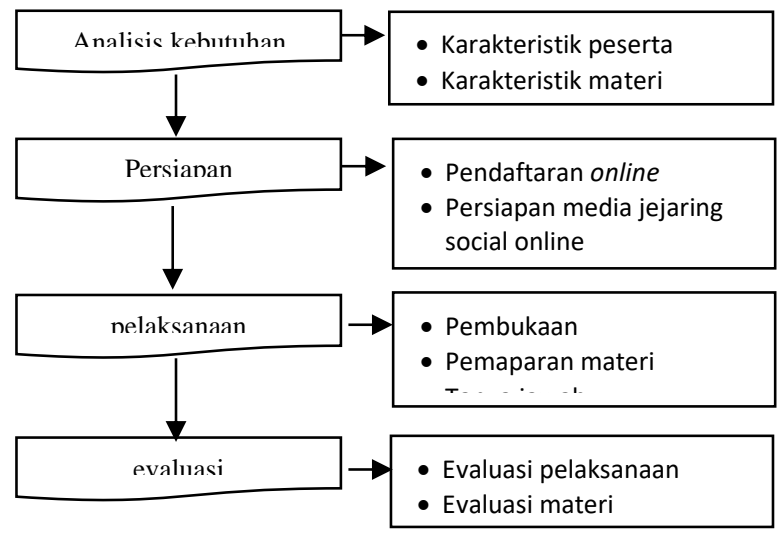

Gambar 1. Tahapan sosialisasi COVID-19 berbasis daring

Alat dan bahan yang digunakan dalam sosialisasi ini adalah laptop, software ms word, koneksi internet, media dalam sosialisasi ini adalah power point, rekaman suara, sosialisasi disampaikan melalui jejaring sosial " telegram", alasan pemilihan media ini karena dapat menampung banyak 
anggota dan relatif sedikit menggunakan data internet sehingga dapat dijangkau oleh masyarakat pelosok dengan koneksi internet yang lambat.

\section{Hasil}

Pelaksanaan pengabdian masyarakat ini dilakukan secara online diikuti oleh 373 peserta, namun hanya 240 yang mengisi formulir daftar ulang peserta karena koneksi internet kurang sehingga tidak dapat mengakses formulir tersebut, peserta berasal dari berbagai provinsi di seluruh Indonesia, sebagian besar berasal dari jawa timur (Tabel 1). Pelaksanaan sosialisasi dilakukan secara online karena mengikuti aturan pemerintah untuk mencegah penularan COVID-19 dengan menghindari kerumunan dan mengumpulkan orang dalam jumlah banyak.

Tabel 1. Karakteristik demografik peserta sosialisasi COVID-19 berbasis daring

\begin{tabular}{|c|c|c|c|}
\hline Karakteristik & kategori & Jumlah (n) & $\%$ \\
\hline \multirow[t]{3}{*}{ Jenis kelamin } & Laki laki & 158 & 65,5 \\
\hline & perempuan & 82 & $34,4 \%$ \\
\hline & total & 240 & $100 \%$ \\
\hline \multirow[t]{8}{*}{ Pendidikan } & Doktor & 6 & $2,5 \%$ \\
\hline & Magister & 20 & $8,3 \%$ \\
\hline & Profesi & 30 & $12,5 \%$ \\
\hline & Sarjana & 113 & $47,1 \%$ \\
\hline & Diploma & 22 & $9,2 \%$ \\
\hline & SD,SMP,SMA & 29 & $12,1 \%$ \\
\hline & lainnya & 20 & $8,3 \%$ \\
\hline & total & 240 & $100 \%$ \\
\hline \multirow[t]{8}{*}{ Pekerjaan } & Mahasiswa & 154 & $63,9 \%$ \\
\hline & Karyawan & 33 & $13,7 \%$ \\
\hline & Dosen & 22 & $9,1 \%$ \\
\hline & Wiraswasta & 5 & 2,1 \\
\hline & Swasta & 7 & $2,9 \%$ \\
\hline & Tidak bekerja & 7 & $2,9 \%$ \\
\hline & lainnya & 12 & $5,4 \%$ \\
\hline & total & 240 & $100 \%$ \\
\hline
\end{tabular}


Dari tabel diatas tampak peserta sosialisasi sebagian besar laki laki, hampir separuhnya pendidikan sarjana, bahkan terdapat $2.5 \%$ sudah berpendidikan doktor.

Pada tahapan analisis tim menemukan karakteristik peserta yang tinggal di kepulauan dengan koneksi internet yang kurang, karena itu dipilih menggunakan media jejaring sosial "telegram" dan materi disampaikan dalam bentuk power point dan rekaman suara, alasannya agar peserta dapat mendownload serta mengulang materi tersebut kapan saja dan dimana saja. Penggunaan video converence tidak dilakukan karena menggunakan aplikasi tersebut memerlukan koneksi internet yang lancar.

Pada tahap pelaksaan acara dipandu oleh moderator, yang mengatur jalannya sosialisasi. Dimulai dari registrasi peserta menggunakan formulir online, dilanjutkan dengan pemaparan materi oleh narasumber selama 45 menit. Pada saat pemaparan materi hanya moderator dan narasumber yang dapat mengirimkan pesan dan berkomentar dalam group jejaring sosial. Setelah pemaparan materi peserta dapat bertanya melalui pesan di group. Pemateri langsung menyampaikan jawaban di group tersebut. Pelaksanaan sosialisasi dilakukan dalam jejaring sosial telegram, seperti gambar sebagai berikut :

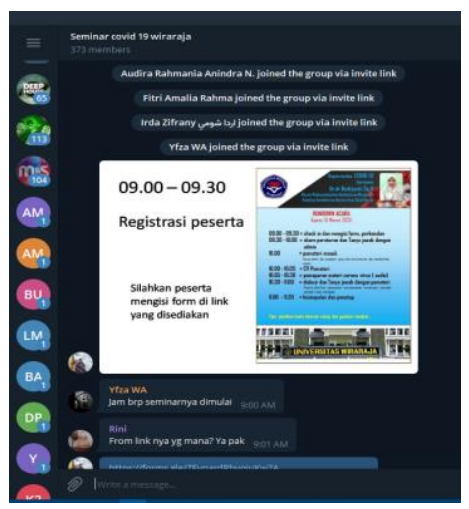

Gambar 2. Kegiatan sosialisasi yang dilaksanakan berbasis daring

Pelaksanaan sosialisasi online menggunakan prinsip pembelajaran online. Terdapat 2 macam pembelajaran berbasis online, synchronous dan 
asynchronous. Dalam Pembelajaran synchronous pemateri dan peserta dapat berinteraksi real time layaknya tatap muka langsung. Meskipun memiliki kelebihan interaksi yang mirip tatap muka langsung, namun metode ini memiliki kekurangan yaitu membutuhkan sumber daya yang besar terutama koneksi internet yang cepat dan stabil. Materi yang disampaikan tidak dapat diulang lagi sehingga tidak cocok untuk daerah yang sumber daya internet yang kurang. Sedangkan pembelajaran asynchronous memiliki kelebihan materi yang dapat diulang ulang dan lebih sedikit sumberdaya internet. Hal ini yang menjadi dasar pemilihan metode sosialisasi menggunakan media sosial "telegram"

Tahap evaluasi dilakukan setelah acara selesai. Peserta menyampaikan masukan dan saran dalam group tersebut. Saran tidak disampaikan dalam formulir elektronik karena peserta mengeluh tidak dapat mengisi formulir terkendala koneksi internet yang kurang. Evaluasi pelaksanaan kegiatan dilakukan setelah selesai acara oleh tim. Hasil evaluasi menunjukkan kegiatan sudah berjalan baik, terbatasnya internet peserta sosialisasi menjadi kendala dari beberapa peserta, namun peserta dapat mengulang materi setelah mendapatkan koneksi internet yang baik. Evaluasi materi dan narasumber dilakukan dengan google form. Peserta juga memberikan evaluasi langsung di group media sosial sesaat selesai acara. Hasil evaluasi yang disampaikan peserta sudah bagus, materi yang disampaikan sangat terkini dan sesuai kondisi saat ini seperti yang disampaikan oleh peserta sebagai berikut:

"Materi yang disampaikan bagus, dan sesuai kondisi terkini, pemateri juga sangat menguasai materi" Sedangkan saran yang disampaikan oleh peserta dirangkum oleh panitia sebagai berikut : sebagian besar peserta telah puas dengan pelaksanaan, dan berharap dilaksanakan sosialisasi yang selanjutnya. Salah satu saran yang disampaikan oleh peserta adalah sebagai berikut: "Saran untuk seminar selanjutnya tetap dengan materi COVID-19 ttg social distancing, lockdown dan menghadirkan pasien yang sudah sembuh dari COVID-19 agar bisa berbagi pengalaman secara langsung." 


\section{Diskusi}

Penyuluhan sosialisasi penyakit coronavirus dengan mengumpulkan masyarakat di era pandemi justru berpotensi penyebaran coronavirus, sehingga penyuluhan menggunakan media online menjadi pilihan utama, meskipun sosialisasi seperti ini membutuhkan koneksi internet.Keterbatasan koneksi internet terutama di daerah kepulauan yang belum ada koneksi $4 \mathrm{G}$ menyebabkan video converence tidak mungkin dilakukan. sehingga alternatif memilih media yang lebih hemat bandwith internet yaitu "telegram". materi disampaikan dalam bentuk power point dan rekaman suara, sehingga peserta dapat mengunduh serta mengulang materi tersebut kapan saja.

Meskipun terdapat disparitas koneksi internet, namun sosialisasi online masih memungkinkan dilaksanakan. Belajar dari rumah membuat mereka tidak merasakan tekanan sebaya yang biasa mereka rasakan ketika belajar bersama teman di dalam perkuliahan yang dilakasanakan secara tatap muka. Ketidakhadiran dosen secara fisik juga membuat mereka tidak merasa canggung dalam mengemukakan pendapat mencari informasi mengenai materi kuliah dan tugas-tugas yang diberikan kepada mereka. Pelaksanaan pembelajaran online memungkinkan mahasiswa untuk mengikuti perkuliahan dari rumah masing-masing. Hal ini mendorong munculnya perilaku social distancing dan meminimalisir kemungkinan munculnya kerumunan mahsiswa di kampus. Dua hal ini merupakan langkah-langkah yang direkomendasikan WHO dalam menekan penyebaran COVID- 19. Meski demikian, pembelajaran online di daerahdaerah yang tidak dijangkau jaringan internet harus diawasi karena berpotensi memunculkan kerumunan di area-area tertentu yang justru meningkatkan kemungkinan penyebaran COVID-19.

\section{Kesimpulan}

Pelaksanaan sosialisasi berlangsung dengan lancar meskipun terkendala dengan koneksi internet yang lambat, peserta dapat mengikuti dan mengulang materi karena materi dengan kapasitas kecil sehingga dapat 
diunduh dengan mudah dan dapat dijangkau oleh peserta dengan koneksi internet yang minim. Saran untuk sosialisasi selanjutnya perlu dirumuskan sosialisasi online untuk daerah dengan keterbatasan koneksi internet dengan memanfaatkan media radio atau televisi.

\section{Pengakuan/Acknowledgements}

Ucapan terima kasih disampaikan kepada Dekan Fakultas Ilmu Kesehatan, dan Rektor Universitas Wiraraja, Dekan Fakultas Kedokteran, dan Rektor Universitas Syiah Kuala Banda Aceh.

\section{Daftar Referensi}

Anonymous. (2020). Pedoman Pencegahan dan Pengendalian Coronavirus

Disease (COVID-19). Gerakan Masyarakat Hidup Sehat. Kemenkes RI;100-115.

Ahn DG, Shin HJ, Kim MH, Lee S, Kim HS, Myoung J, et al. (2020).

Current Status of Epidemiology, Diagnosis, Therapeutics, and Vaccines for Novel Coronavirus Disease 2019 (COVID-19). Journal of Microbiology and Biotechnollogy. 30:313-24.

Ahmed F, Zviedrite N. and Uzicanin, A. (2018) "Effectiveness of workplace social distancing measures in reducing influenza transmission: A systematic review," BMC Public Health. BMC Public Health, 18(1), pp. 1-13

Bedford, J. et al. (2020) "COVID-19: towards controlling of a pandemic," The Lancet, 395(10229), pp. 1015-1018. doi: 10.1016/S01406736(20)30673-5

Hoffmann, M. et al. (2020) "SARS-CoV-2 Cell Entry Depends on ACE2 and TMPRSS2 and Is Blocked by a Clinically Proven Protease Inhibitor," Cell, pp. 1-10.

Guo, YR. et al. (2020) "The origin, transmission and clinical therapies on coronavirus disease 2019 (COVID-19) outbreak - an update on the status," Military Medical Research. Military Medical Research, 7(1), p. 11

Kelso JK, Milne GJ and Kelly H. (2009) "Simulation suggests that rapid 
activation of social distancing can arrest epidemic development due to a novel strain of influenza," BMC Public Health, 9, pp. 1-10.

$\mathrm{Li}, \mathrm{X}$. et al. (2020) "Molecular immune pathogenesis and diagnosis of COVID-19," Journal of Pharmaceutical Analysis. Elsevier Ltd, 19(xxxx), pp. 1-7. doi: 10.1016/j.jpha.2020.03.001

Maharaj S. and Kleczkowski A. (2012) "Controlling epidemic spread by social distancing: do it well or not at all.," BMC public health, 12(June 2014), p. 679

Pawelek KA, Salmeron C, and Valle SD. (2015) "Connecting within and between-hosts dynamics in the influenza infection-staged epidemiological models with behavior change," Journal of Coupled Systems and Multiscale Dynamics, 3(3), pp. 233-243

Shereen, M. A. et al. (2020) "COVID-19 infection: Origin, transmission, and characteristics of human coronaviruses," Journal of Advanced Research. THE AUTHORS, 24, pp. 91-98. doi: 10.1016/j.jare.2020.03.005

World Health Organization. Assessment of Risk Factor for Coronavirus Disease 2019 (COVID-19) in Health Workers: Protocol for CaseControl Study. WHO-2019-nCoV HCW_RF_CaseControlProtocol2020.1-eng.pdf.

Yanti, B., Wahyudi, E., Wahiduddin, W., Novika, R. G. H., Arina, Y. M. D., Martani, N. S., \& Nawan, N. (2020). Community Knowledge, Attitudes, and Behavior Towards Social Distancing Policy As Prevention Transmission of Covid-19 in Indonesia. Jurnal Administrasi Kesehatan Indonesia, 8(2), 4. https://doi.org/10.20473/jaki.v8i2.2020.4-14

Yanti, B., \& Hayatun, U. (2020). Peran pemeriksaan radiologis pada diagnosis Coronavirus disease 2019. 53-57

Zhu, N. et al. (2020) "A novel coronavirus from patients with pneumonia in China, 2019," New England Journal of Medicine, 382(8), pp. 727733. doi: 10.1056/NEJMoa2001017 